\title{
The detection of thermophilous forest hotspots in Poland using geostatistical interpolation of plant richness
}

\author{
Marcin Kiedrzyński*, Janina Jakubowska-Gabara \\ Department of Geobotany and Plant Ecology, Faculty of Biology and Environmental Protection, University of Łódź, Banacha 12/16, 90-237 Łódź, Poland
}

\begin{abstract}
Attempts to study biodiversity hotspots on a regional scale should combine compositional and functionalist criteria. The detection of hotspots in this study uses one ecologically similar group of high conservation value species as hotspot indicators, as well as focal habitat indicators, to detect the distribution of suitable environmental conditions. The method is assessed with reference to thermophilous forests in Poland - key habitats for many rare and relict species. Twenty-six high conservation priority species were used as hotspot indicators, and ten plant taxa characteristic of the Quercetalia pubescenti-petraeae phytosociological order were used as focal habitat indicators. Species distribution data was based on a $10 \times 10 \mathrm{~km}$ grid. The number of species per grid square was interpolated by the ordinary kriging geostatistical method. Our analysis largely determined the distribution of areas with concentration of thermophilous forest flora, but also regional disjunctions and geographical barriers. Indicator species richness can be interpreted as a reflection of the actual state of habitat conditions. It can also be used to determine the location of potential species refugia and possible past and future migration routes.
\end{abstract}

Keywords: biodiversity hotspots; geostatistical interpolation; focal habitats; indicator species; ordinary kriging; Poland; thermophilous forests

\section{Introduction}

Attempts to analyze biodiversity hotspots on a regional scale should combine compositional and functionalist criteria [1]. Compositional criteria have typically relied on determining the taxonomical richness or the occurrence of rare, threatened and endemic species [2-4]. The functionalist approach focuses on dynamic processes and indication of possible changes in the distribution of hotspots and their characteristics in the future [1,5].

On a regional scale, it seems to be difficult to produce a single map of hotspots for different groups of species that differ ecologically [6], which is based on different diversity measures [4]. The detection of hotspots in this study uses one ecologically similar group of high conservation value species as hotspot indicators, as well as focal habitat indicators, to detect the distribution of suitable environmental conditions.

Species representative of key habitats of regional biodiversity may be used as indicators of potential habitats for rare species. The study assumes that patterns of focal habitat distribution can be included in the functionalist approaches to hotspot detection. This approach is similar to that of

\footnotetext{
* Corresponding author. Email: kiedmar@biol.uni.lodz.pl
}

Handling Editor: Jacek Herbich
Hughes et al. [7] who propose that emphasis should be placed on preserving the connectivity of widely-dispersed species, combined with intensive protection of quite localized hotspots.

The study evaluates this method with regard to thermophilous forests on Polish territory. They play an important role as habitats for many rare and threatened plants, and are one of the most species-rich forest ecosystems in Central Europe [8-10]. In the European Union, most are protected in the Natura 2000 network as natural habitats [10,11]. Concentrations of thermophilous plants in Central Europe are typical of the complexes of forest, scrub, fringe and grassland vegetation that remained in the relict "dry islands" [12-14]. The long-lasting existence of the Central European forests with helio- and thermophilous flora was probably possible in combination of specific habitat conditions and the regime of anthropo-zoogenic, fire disturbance and large herbivore pressure or special forestry practices, such as coppicing [9,15-19]. During recent decades, a rapid extinction of open forests has been observed as a result of the expansion of mesophilic trees and shrubs after cessation of such traditional forms of forest use as grazing and litter raking, and the overall anthropogenic eutrophication of soils $[9,20,21]$. As the Polish territory to the north of the Carpathians and the Sudetes Mts. offers various habitat conditions in the glacial, periglacial and highland landscapes, the question arises: 
how large are the areas with a concentration of the rarest thermophilous forest plants in these different landscapes?

The aim of this study was twofold: (i) to indicate the hotspots of thermophilous forest flora in Poland using high conservation priority species as indicators, and (ii) to detect areas with suitable conditions for thermophilous forest flora using the focal habitat indicators. Generalization of indicator species richness was made by using geostatistical interpolation methods [22,23].

\section{Material and methods}

\section{Study area}

The study was conducted in the Polish territory, mostly lowland and upland areas between the Carpathians, the Sudetes and the Baltic Sea in Central Europe, stretching between the north latitudes $49^{\circ} 00^{\prime}-54^{\circ} 50^{\prime}$ and the east longitudes $14^{\circ} 07^{\prime}-24^{\circ} 08^{\prime}$. The study area is located in the transition zone between the temperate oceanic (Atlantic) climate in the west and the moderate continental climate in the east. The potential natural vegetation is mainly mesophilic oakhornbeam forests, beech forests and mixed pine-oak forests [24]. The patches of thermophilous forests are of extrazonal character $[9,25]$.

Hotspot distribution was analyzed in the following landscapes: young glacial, periglacial (old glacial) and highlands/ mountainand in relation to the maximum extents of the Vistulian (Würm) and Wartanian (Riss) Glaciations, according to Marks et al. [26].

\section{Hotspot indicators}

The species from the "Red list of vascular plants in Poland" [27] and from the "Polish red data book of plants" [28] that occur most frequently in thermophilous forests and thermophilous fringe communities was chosen. Twenty-six taxa were identified: Adenophora liliifolia, Carduus collinus, Cephalanthera damasonium, C. longifolia, C. rubra, Cypripedium calceolus, Dictamnus albus, Dorycnium herbaceum, Epipactis microphylla, Euphorbia epithymoides, Festuca amethystina subsp. ritschlii, Inula germanica, Lathyrus pisiformis, Buglossoides purpurocaerulea (=Lithospermum purpurocaeruleum), Melampyrum cristatum, Orchis pallens, Orchis purpurea, Orchis tridentata, Peucedanum alsaticum, Potentilla rupestris, Prunus fruticosa, Quercus pubescens, Rosa gallica, Thesium ebracteatum, Veratrum nigrum and Veronica paniculata. All plant nomenclature is given according to Tutin et al. [29]. The species richness analysis is based on plant distribution data from the Atlas of vascular plant distribution in Poland, ATPOL [30], collected on the basis of a $10 \times 10 \mathrm{~km}$ grid.

\section{Focal habitat indicators}

Indicators of thermophilous forests north of the Carpathians and Sudetes Mts. belong to a well-defined phytosociological group of species characteristic of subcontinental and submediterranean oak forests Quercetalia pubescenti-petraeae Klika 1933 corr. Moravec in Beguin et Theurillat $[8,25,31,32]$. Ten taxa characteristic of the Quercetalia pubescenti-petraeae phytosociological order, after Matuszkiewicz [25], were chosen: Campanula persicifolia, Hypericum montanum, Lathyrus niger, Melittis melissophyllum, Potentilla alba, Pulmonaria angustifolia, Pulmonaria mollis, Ranunculus polyanthemos, Sorbus torminalis, and Tanacetum corymbosum ssp. corymbosum. Again, the richness of the above-mentioned indicators (per square $10 \times 10 \mathrm{~km}$ ) was calculated with the use of data on the distribution of species from the Atlas of vascular plant distribution in Poland - ATPOL [30].

\section{Spatial interpolation of species richness}

The interpolation of species richness was performed by ordinary kriging $(\mathrm{OK})$ to detect its general spatial pattern. $\mathrm{OK}$ is one of the most commonly used methods for geostatistical interpolation of data in the environmental sciences $[22,23,33]$.

Maps of the distribution of indicator species from the ATPOL atlas [30] were digitized with ArcGIS Desktop ${ }^{\text {Tw }} 9.2$ software [34]. Midpoints were generated for the squares $(10 \times 10 \mathrm{~km})$ and species richness was calculated for each. Because the data being arranged on a regular grid at a fairly high density, hence the values on the map of interpolation uncertainties were evenly distributed $[22,35]$.

To determine the spatial structure of species richness, a semivariogram was calculated $[22,36]$. Basic spatial parameters of semivariogram such as nugget variance $(\mathrm{Co})$, structural variance $(C)$, sill $(\mathrm{Co}+C)$ and range $(A)$ were calculated $[22,37]$. The best fit model, spherical, exponential or Gaussian, was selected. Models were assessed using two methods. The first was the residual sum of squares (residual SS), which provides an exact measure of how well the model fits the variogram data: the lower the reduced sum of squares, the better the fit of the model. The second was the regression coefficient $r^{2}$, which indicates how well the model fits to the variogram data, although it is not as sensitive or robust as the residual SS for best-fit calculations [37]. The parameters of the model that best fit the empirical semivariogram were further used for spatial interpolation of data. For search methods, a radius equal to the range $(A)$ in the model that best fit the semivariogram, and a cell size of $10 \times 10 \mathrm{~km}$ was used. Geostatistical analysis was performed using GS $+9^{\text {max }}$ Gamma Design Software [37].

The interpolation produced raster data assigned with values for indicator species richness. Visualizations of the interpolation results, statistics and correlation analysis were

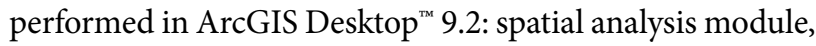
multivariate analysis module and band collection statistic tool [34].

\section{Results}

\section{Modeling the spatial structure of indicator species richness}

The exponential model demonstrated the best fit to the empirical semivariogram demonstrating the spatial structure of richness of hotspot and habitat indicator species in the analyzed area (Tab. 1). In comparison with the other models, it had the smallest residual SS ( 0.0067 for hotspot indicator richness and 0.076 for habitat indicator richness) and a correlation coefficient $r^{2}$ closest to unity $(0.901$ and 0.940 , respectively). Its nugget variance was moderate ( 0.106 and 
0.46) and the range was the greatest (40 $800 \mathrm{~m}$ and $63000 \mathrm{~m}$ ), indicating the distance to which the richness of the studied species is spatially dependent. In line with the results of variogram modeling, the $\mathrm{OK}$ interpolation was based on the exponential model. The radius of the search used in $\mathrm{OK}$ was the determined range, i.e. 40800 and $63000 \mathrm{~m}$.

Tab. 1 Parameters of variogram model types examined to choose a model that best fitted to the experimental data of richness of hotspot and habitat indicators of thermophilous forests in Poland.

\begin{tabular}{lccccc}
\hline $\begin{array}{l}\text { Variogram } \\
\text { model type }\end{array}$ & $\mathrm{Co}$ & $\mathrm{Co}+\mathrm{C}$ & $A(\mathrm{~m})$ & $\begin{array}{c}\text { Residual } \\
\text { SS }\end{array}$ & $r^{2}$ \\
\hline
\end{tabular}

Richness of hotspot indicators

$\begin{array}{llllll}\text { Spherical } & 0.028 & 1.074 & 30900 & 0.0117 & 0.826 \\ \text { Expotential } & \mathbf{0 . 1 0 6} & \mathbf{1 . 0 7 8} & \mathbf{4 0 8 0 0} & \mathbf{0 . 0 0 6 7} & \mathbf{0 . 9 0 1} \\ \text { Gaussian } & 0.148 & 1.074 & 26673 & 0.0116 & 0.828\end{array}$

Richness of habitat indicators

\begin{tabular}{llllll} 
Spherical & 0.16 & 3.98 & 43000 & 1.191 & 0.836 \\
Expotential & $\mathbf{0 . 4 6}$ & $\mathbf{4 . 0 1}$ & $\mathbf{6 3 0 0 0}$ & $\mathbf{0 . 0 7 6}$ & $\mathbf{0 . 9 4 0}$ \\
Gaussian & 0.61 & 3.96 & 38105 & 0.181 & 0.840 \\
\hline
\end{tabular}

Values in bold type - parameters of the best fitted model.

\section{Species richness, its interpolation and correlations}

The original species number of both hotspot and habitat indicators range from 0 to 10 species per $10 \mathrm{~km}$ square (Fig. 1a). However, although the species pool of habitat indicators (10) is less than half of hotspots indicators (26), mean richness of habitat indicators is 3 times higher (Fig. 1a). The number of cells (i.e. area occupied on the maps) with close to mean values of habitat indicator richness was emphasized after the spatial interpolation of data (Fig. 1a,b). In both cases, the kriging interpolation reduced the species richness ranges, from 10 per square to 4.5 for hotspot and 6.9 for habitat indicator species. The correlation coefficient between raster layers, which represent the richness of hotspot and habitat indicators, is 0.56 for original data, and 0.64 after ordinary kriging interpolation.

\section{Hotspot distribution}

The upland areas in the south of the Wartanian Glaciation (the Polish Uplands and the Sudetic Foreland) are the richest in hotspots. In this part of the country occur 10 squares with original number of indicator species equal 7 and above (Fig. 2a, , squares No. 2-11) and five hotspots, where the interpolated richness ranged from 3.1 to 4.0 species and in three of them to 4.5 (Fig. 2b). The hotspots with richness more than 2.0 occupy $10 \%$ of this part of the country (Tab. 2).

The second center of hotspots is located in the Wielkopolska Lowland and Masurian Lakeland, in the young glacial landscape (Fig. 2b). However, only one hotspot with original number of species equal 9 (Fig. 2a, square No. 1) and with (a)

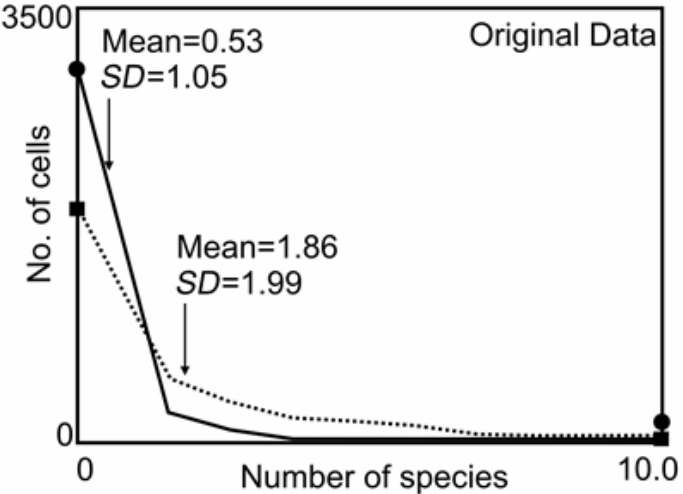

(b)

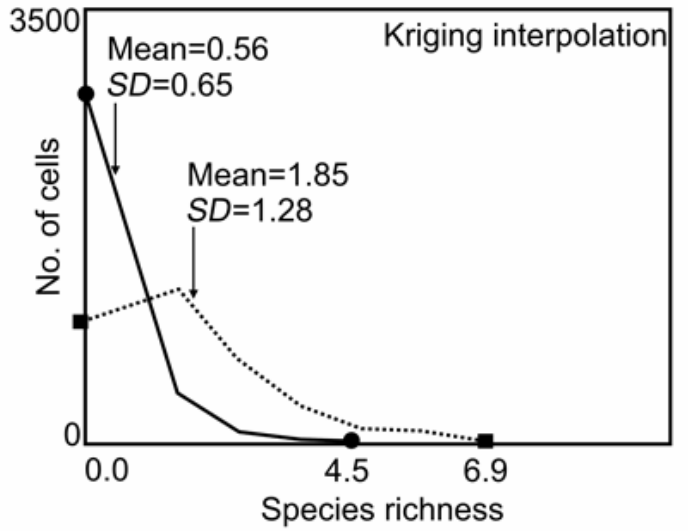

Fig. 1 The schedule of cells in raster layers which presents the richness of the hotspot indicators (solid line) and habitat indicators (dashed line) of thermophilous forests in Poland. a Original data. b Data after ordinary kriging interpolation; species richness calculated per square $10 \times 10 \mathrm{~km}$. $S D$ - standard deviation.

interpolated richness up to 4.0 is located in this part of the country: the Bielinek nature reserve (Fig. 2a,b). The rest of hotspots with interpolated richness up to 3.0 are dispersed and isolated (Fig. 2b); the areas with richness more than 2.0 occupy $1.8 \%$ of the area.

A large disjunction between areas with hotspots was identified in central Poland (Fig. 2b), where the areas with richness of hotspot indicators more than 2.0 occupy only $0.1 \%$ (Tab. 2). This part of Poland is situated between the Vistulian and the Wartanian Glaciations in the old glacial landscape (Fig. 2b).

The distribution of suitable habitats i.e. areas with richness of indicator species is higher than 2.0 (close to mean value 1.85 - for the whole study area) is similar to general pattern of hotspots distribution (Fig. 2b,c). Suitable habitats are widely distributed (areas with richness $>2.0$ occupy $36.0 \%$ ) than hotspots (areas with richness $>2.0$ occupy $4.5 \%$ ) and therefore can indicate possible landscape connections between hotspots. Five areas with high richness of habitat indicators but without hotspots occur: one in the eastern part of the Polish Uplands, with richness of habitat indicators up to 6.9 and four in the north-eastern and central parts of the country, with richness up to 6.0 (Fig. 2b,c). 
(a)

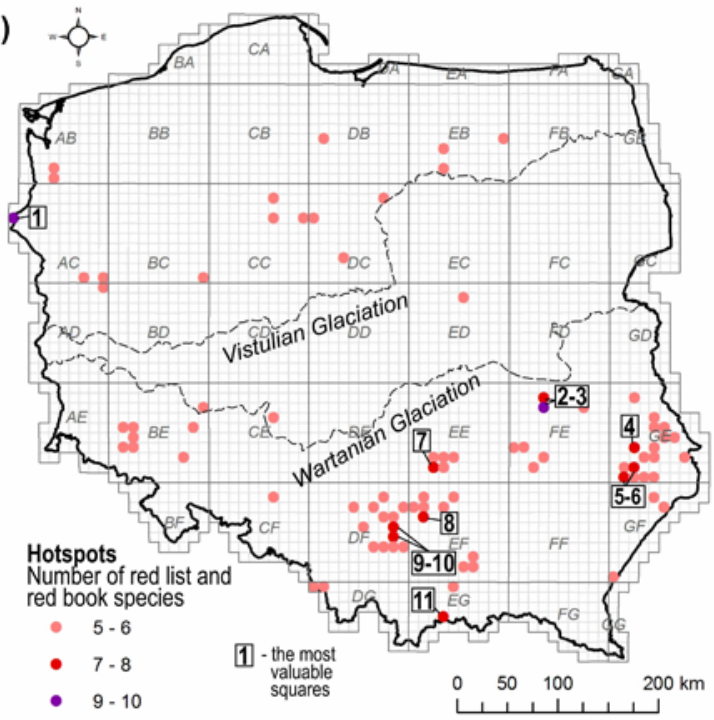

(b)

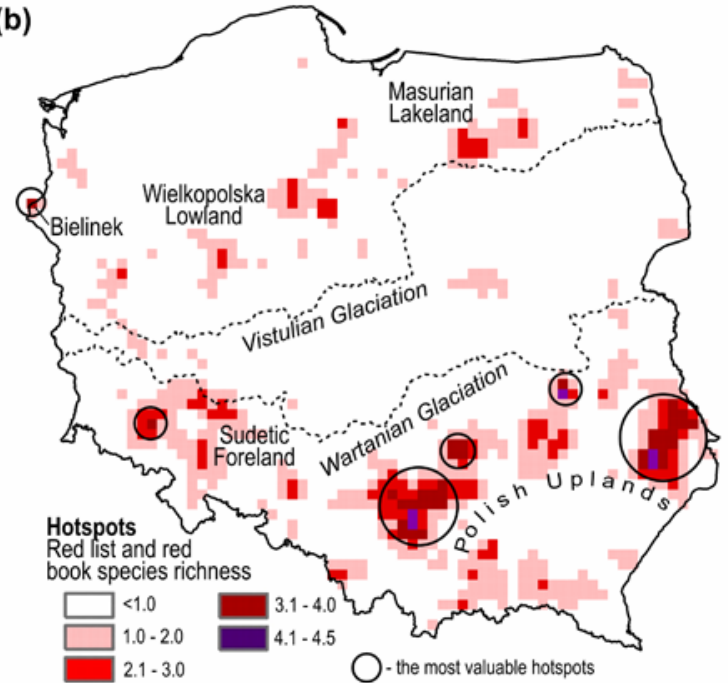

(c)

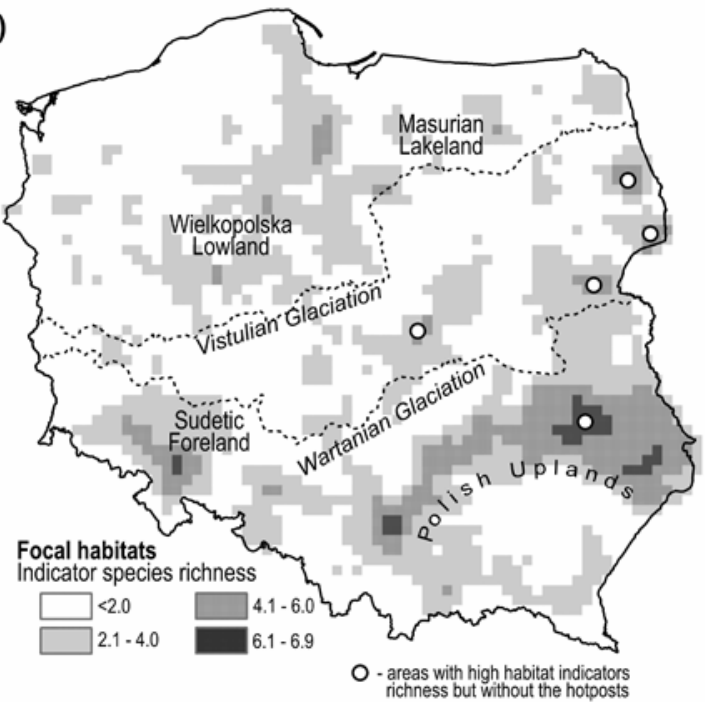

Fig. 2 Thermophilous forest hotspots in Poland identified according to original data (a), and geostatistical interpolation (b), compared with the distribution of their focal habitats (c). The most valuable squares in (a): 1 - Bielinek, 2-3 - Puławy-Kazimierz Dolny, 4 - Izbica, 5-6 - Zamość-Zwierzyniec, 7 - Bolmin, 8 - Racławice, 9-10 - Ojców-Bolechowice, 11 - Pieniny. Species richness in $\mathbf{b}$ and $\mathbf{c}$ is expressed by ordinary kriging interpolation. Maximum glaciation extents after Marks et al. [26]: Vistulian Glaciation (115-12 × $10^{3}$ years BP), Wartanian Glaciation $\left(210-130 \times 10^{3}\right.$ years $\left.\mathrm{BP}\right)$.
Tab. 2 The area $\left(\mathrm{km}^{2} \times 100\right)$ and percentage cover (\%) of increasing interpolated richness of hotspot indicators in the three parts of the study area distinguished according to the glaciation ranges.

\begin{tabular}{|c|c|c|c|c|c|c|c|c|}
\hline \multirow{3}{*}{$\begin{array}{l}\text { Parts of the study } \\
\text { area according to the } \\
\text { glaciation ranges }\end{array}$} & \multicolumn{8}{|c|}{ Interpolated richness of hotspot indicators } \\
\hline & \multicolumn{2}{|c|}{$>1.0$} & \multicolumn{2}{|c|}{$>2.0$} & \multicolumn{2}{|c|}{$>3.0$} & \multicolumn{2}{|c|}{$>4.0$} \\
\hline & $A$ & $\%$ & $A$ & $\%$ & $A$ & $\%$ & $A$ & $\%$ \\
\hline North of the Vistulian & 126 & 10.8 & 21 & 1.8 & 1 & 0.1 & 0 & 0.0 \\
\hline $\begin{array}{l}\text { Between Vistulian } \\
\text { and Wartanian }\end{array}$ & 32 & 4.1 & 1 & 0.1 & 0 & 0.0 & 0 & 0.0 \\
\hline $\begin{array}{l}\text { South of the } \\
\text { Wartanian }\end{array}$ & 390 & 33.4 & 118 & 10.1 & 41 & 3.5 & 5 & 0.4 \\
\hline
\end{tabular}

\section{Discussion}

The geostatistical analysis indicates that the maximal distance for significant spatial correlation is $40.8 \mathrm{~km}$ for hotspot species richness and $63.0 \mathrm{~km}$ for habitat indicator richness. Moreover, the mean value for hotspot indicator richness is less than one third of that of the habitat indicators. These results imply that the hotspot indicators, and by extension, the most threatened thermophilous species, occupy rather isolated environmental islands in comparison to the habitat indicators, which are rather well dispersed. Moderate positive correlations were seen between the hotspot and habitat indicators: the correlation coefficient was found to be 0.56 for the original data and 0.64 after interpolation. Some areas with high habitat indicator richness but with a low incidence of hotspot indicators were detected. They could act as sites where the threatened thermophilous plants may be found in the future, or possibly as environmental corridors.

The ordinary kriging method produced generalized map of indicator species richness. The result can be used as an background layer in phylogeographical studies, spatial modeling, metapopulation demography and landscape interaction modeling. Spatial patterns in actual species distribution are easier to identify after the data is subjected to interpolation. Interpolation of floristic data eliminates also the possible lack of precision or random errors in the location of species, or uneven precision in the examination of the study area. It is important to note that the data was analyzed on a large spatial scale, and was collected for many years by many researchers. The results of this study confirm that ordinary kriging is a good method for the identification of spatial patterns in species richness, as previously noted by other studies $[4,38-40]$.

The distribution of the most important areas for rare plants occurring in thermophilous forests in Polish territory was identified. They are located in the Polish Uplands of the southern and southeastern part of the country, and in the Sudetic Foreland. In both cases, these are areas with a high concentration of calcium in the soil, a favorable microclimate on the southern hill slopes and the nearest location to the glacial refugia in southern and southeastern Europe [41].

The lowland center of concentration of the studied species is located in the young glacial landscape of the Wielkopolska and Masuria regions, within the maximum extent of the 
Vistulian Glaciation [26]. The occurrence of thermophilous plants is here connected with the presence of young soils rich in calcium and a pronounced topography [42]. Of special importance is the Bielinek nature reserve on the steep slope of the Odra river valley, which represents the only location of Quercetum pubescenti-petreae submediterrianian oak forests in the country $[43,44]$. Analysis of the occurrence of the rarest plants from the Polish red list and red book confirms the high concentration of endangered forest thermophilous flora at this site, in comparison with other lowland hotspots.

The area of central Poland was found to be a regional disjunction in hotspots of rare thermophilous forest flora. The richness of hotpots and focal habitat indicators was found to be low to the south of the extents of Pleistocene glaciers (Vistulian and Wartanian), where sandy deposits and humid habitats are most common [26]. These areas constitute geographic barriers for thermophilous plants.

An analysis of species richness distribution could also be useful for defining the possible entry areas of thermophilous plants into the Polish territory during their Holocene migration (Fig. 3), which have been discussed in the literature for the last few decades [45-47]. The present study suggests that great migration possibilities existed from the Ukrainian Uplands and along the northern peripheries of the Carpathians to the Polish Uplands, and from the Pannonian Basin through the Moravian Gate and the Beskid Niski Mts (Fig. 3). Our analysis also emphasizes the role of the Poprad River and the Dunajec river valleys as corridors for the thermophilous flora to pass through the Carpathians, which was previously suggested by Cyunel [48] and Pawłowski [49]. Taking into consideration indicated habitat barriers in the central part of the country, the migration to the Wielkopolska and the Masuria regions probably took place from northwestern and northeastern directions, respectively (Fig. 3), as suggested by Paul [47]. The current rate of loss of open forests is so great that, in the case of thermophilous forest flora, the anthropogenic isolation of forest complexes and limited dispersion abilities of plants has resulted in the formation of more isolated in situ refugia, and only a minor migration of species can be observed.

In order to manage biodiversity, it is important to know where it is and how it is arranged at different spatial scales [50]. There is an increasing awareness that conservation on a small scale is not sufficient to protect the processes

\section{Acknowledgments}

We wish to thank Professor Ladislav Mucina for the very constructive comments on the previous version of the manuscript. We thank the editors and anonymous reviewers for their remarks and comments, which helped us to improve the manuscript. This study was financially supported by Department of Geobotany and Plant Ecology, University of Łódź.

\section{Authors' contribution}

The following declarations about authors' contributions to the research have been made: concept of the study: MK; GIS-geostatistical analysis: MK; writing: MK, JJG.

\section{References}

1. Whittaker RJ, Araújo MB, Jepson P, Ladle RJ, Watson JEM, Willis KJ. Conservation biogeography: assessment and prospect. Divers Distrib. 2005;11(1):3-23. http://dx.doi.org/10.1111/j.1366-9516.2005.00143.x at a landscape level. The identification of priority areas, or hotspots, is a key component of conservation biogeography $[51,52]$. As the results of hotspot detection depend on criteria and produce alternative maps of potential conservation prioritization [53], other, more structural and functional criteria should be incorporated in hotspot detection [1], especially in regions which are not rich in endemic species, like the study area presented in this paper.

Modeling the distribution of potential habitats for species is usually based on a variety of environmental features [54-56]. As was shown our study, one of such feature could be the presence of habitat indicator species, since areas with similar environmental characteristics may serve as refugial for groups of species living in a similar habitat. The richness of habitat indicators is an expression of bioclimatic and soil conditions and biological interactions. The richness of habitat indicators can also be understood as a diagnosis of the actual state of habitats on a large spatial scale [57]. Using a species representative of a habitat as an indicator is most justified in areas with well-defined plant or animal ecological assemblages. The use of a combination of hotspot and habitat indicators could give very informative results on regional spatial patterns in flora and fauna.

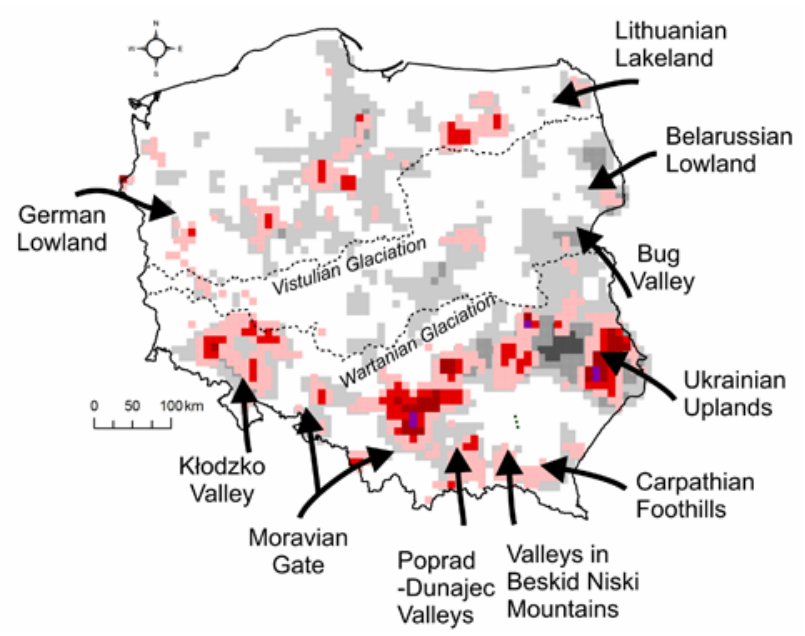

Fig. 3 Potential post-glacial migration routes of thermophilous forest flora into Polish territory on the background of distribution of their current hotspots and focal habitats according to Fig. 2. Maximum extents of Vistulian and Wartanian Glaciations after Marks et al. [26].

2. Whittaker RJ, Willis KJ, Field R. Scale and species richness: towards a general, hierarchical theory of species diversity: towards a general theory of diversity. J Biogeogr. 2001;28(4):453-470. http://dx.doi. org/10.1046/j.1365-2699.2001.00563.x

3. Mittermeier RA, Turner WR, Larsen FW, Brooks TM, Gascon C. Global biodiversity conservation: the critical role of hotspots. In: Zachos FE, Habel JC, editors. Biodiversity hotspots. Berlin: Springer Berlin Heidelberg; 2011. p. 3-22.

4. Feng JM, Zhang Z, Nan RY. Non-congruence among hotspots based on three common diversity measures in Yunnan, south-west China. Plant Ecol Divers. 2011;4(4):353-361. http://dx.doi.org/10.1080/175 50874.2012.697204

5. Williams $\mathrm{PH}$, Araújo MB. Integrating species and ecosystems monitoring for identifying conservation priorities. Eur Conserv. 2000;4:17-18.

6. Cardoso da Silva JM, Cardoso de Sousa M, Castelletti CH. Areas of endemism for passerine birds in the Atlantic forest, South America: 
bird areas of endemism in the Atlantic Forest. Glob Ecol Biogeogr. 2004;13(1):85-92. http://dx.doi.org/10.1111/j.1466-882X.2004.00077.x

7. Hughes TP, Bellwood DR, Connolly SR. Biodiversity hotspots, centres of endemicity, and the conservation of coral reefs: biodiversity of coral reefs. Ecol Let. 2002;5(6):775-784. http://dx.doi. org/10.1046/j.1461-0248.2002.00383.x

8. Chytrý M. Thermophilous oak forests in the Czech Republic: syntaxonomical revision of the Quercetalia pubescenti-petraeae. Folia Geobot. 1997;32(3):221-258. http://dx.doi.org/10.1007/BF02804006

9. Jakubowska-Gabara J. Decline of Potentillo albae-Quercetum Libb. 1933 phytocoenoses in Poland. Vegetatio. 1996;124(1):45-59. http:// dx.doi.org/10.1007/BF00045143

10. Bergmeier E, Petermann J, Schröder E. Geobotanical survey of wood-pasture habitats in Europe: diversity, threats and conservation. Biodivers Conserv. 2010;19(11):2995-3014. http://dx.doi.org/10.1007/ s10531-010-9872-3

11. European Commission. Directive 92/43/EEC of 21 May 1992 on the conservation of natural habitats and of wild fauna and flora. J Eur Communities. 1992;206:7-50.

12. Ellenberg HH. Vegetation ecology of Central Europe. 4th ed. Cambridge: Cambridge University Press; 1988.

13. Mucina L, Kolbek J. Festuco-Brometea. In: Mucina L, Grabherr G, Ellmauer T, editors. Plant communities of Austria. Jena: Gustav Fischer Press; 1993. p. 420-492. (pt 1).

14. Hájková P, Roleček J, Hájek M, Horsák M, Fajmon K, Polák M, et al. Prehistoric origin of extremely species-rich semi-dry grasslands in the Bílé Karpaty Mts. Preslia. 2011;83(2):185-204.

15. Vera FWM. Grazing ecology and forest history. Oxfordshire: CABI; 2000.

16. Ralska-Jasiewiczowa M, Nalepka D, Goslar T. Some problems of forest transformation at the transition to the oligocratic/Homo sapiens phase of the Holocene interglacial in northern lowlands of Central Europe. Veg Hist Archaeobot. 2003;12(4):233-247. http://dx.doi.org/10.1007/ s00334-003-0021-8

17. Roleček J. Formalized classification of thermophilous oak forests in the Czech Republic: what brings the Cocktail method? Preslia. 2007;79:1-21.

18. Jamrichova E, Szabo P, Hedl R, Kunes P, Bobek P, Pelankova B. Continuity and change in the vegetation of a Central European oakwood. Holocene. 2013;23(1):46-56. http://dx.doi.org/10.1177/0959683612450200

19. Szymura TH, Szymura M. Spatial variability more influential than soil $\mathrm{pH}$ and land relief on thermophilous vegetation in overgrown coppice oak forests. Acta Soc Bot Pol. 2013;82(1):5-11. http://dx.doi. org/10.5586/asbp.2013.003

20. Kwiatkowska AJ, Wyszomirski T. Decline of Potentillo albae-Quercetum phytocoenoses associated with the invasion of Carpinus betulus. Vegetatio. 1988;75(1-2):49-55. http://dx.doi.org/10.1007/BF00044625

21. Hédl R, Kopecký M, Komárek J. Half a century of succession in a temperate oakwood: from species-rich community to mesic forest. Divers Distrib. 2010;16(2):267-276. http://dx.doi. org/10.1111/j.1472-4642.2010.00637.x

22. Li J. A review of spatial interpolation methods for environmental scientists. Canberra: Geoscience Australia; 2008.

23. Li J, Heap AD. A review of comparative studies of spatial interpolation methods in environmental sciences: performance and impact factors. Ecol Inf. 2011;6(3-4):228-241. http://dx.doi.org/10.1016/j. ecoinf.2010.12.003

24. Matuszkiewicz W. Potential natural vegetation of Poland, scale 1:300000. Warsaw: Polish Academy of Sciences; 1995.

25. Matuszkiewicz JM. Zespoły leśne Polski. Warsaw: Polish Scientific Publishers PWN; 2001.

26. Marks L, Ber A, Gogołek W, Piotrowska K, editors. Geological map of Poland, scale 1:500000. Warsaw: Polish Geological Institute; 2006.

27. Zarzycki K, Szeląg Z. Red list of the vascular plants in Poland. In: Mirek Z, Zarzycki K, Wojewoda W, Szeląg Z, editors. Red list of plants and fungi in Poland. Cracow: W. Szafer Institute of Botany, Polish Academy of Sciences; 2006. p. 9-20.

28. Zarzycki K, Kaźmierczakowa R, editors. Polish red data book of plants.
Pteridophytes and flowering plants. Cracow: W. Szafer Institute of Botany, Polish Academy of Sciences; 2001.

29. Tutin TG, Heywood VH, Burges NA, Valentine DH, Walters SM, Webb DA, editors. Flora Europaea. Cambridge: Cambridge University Press; 1968. (vol 2-5).

30. Zając A, Zając M, editors. Distribution atlas of vascular plants in Poland. Cracow: Laboratory of Computer Chorology, Institute of Botany, Jagiellonian University; 2001.

31. Müller T. Quercetalia pubescenti-petraeae Klika 33 cor. Moravec in Béguin et Theurillat 84. In: Oberdorfer E, editor. South German plant communities. 4. Forests and scrubs. Jena: Gustav Fischer Press; 1992. p. 119-137.

32. Roleček J. Vegetation types of dry-mesic oak forests in Slovakia. Preslia. 2005;77(3):241-261.

33. Bello-Pineda J, Hernandez-Stefanoni JL. Comparing the performance of two spatial interpolation methods for creating a digital bathymetric model of the Yucatan submerged platform. Pan Am J Aquat Sci. 2007;2(3):247-254.

34. ArcGIS 9.2. Redlands, CA: ESRI; 1999.

35. Burrough PA, Mcdonnell RA. Principles of geographical information systems. Oxford: Oxford University Press; 1998.

36. Isaaks EH, Srivastava RM. An introduction to applied geostatistics. Oxford: Oxford University Press; 1989.

37. Robertson GP. GS+: geostatistics for the environmental sciences. Plainwell, MI: Gamma Design Software; 2008.

38. Valley RD, Drake MT, Anderson CS. Evaluation of alternative interpolation techniques for the mapping of remotely-sensed submersed vegetation abundance. Aquat Bot. 2005;81(1):13-25. http://dx.doi. org/10.1016/j.aquabot.2004.09.002

39. Hernandez-Stefanoni JL, Ponce-Hernandez R. Mapping the spatial variability of plant diversity in a tropical forest: comparison of spatial interpolation methods. Env Monit Assess. 2006;117(1-3):307-334. http://dx.doi.org/10.1007/s10661-006-0885-Z

40. Yasrebi J, Saffari M, Fathi H, Karimian N, Moazallahi M, Gazni R. Evaluation and comparison of ordinary kriging and inverse distance weighting methods for prediction of spatial variability of some soil chemical parameters. Res J Biol Sci. 2009;4(1):93-102.

41. Szafer W. Szata roślinna Polski niżowej. In: Szafer W, Zarzycki K, editors. Szata roślinna Polski. 2nd ed. Warsaw: Polish Scientific Publishers PWN; 1972. p. 17-188.

42. Czubiński Z. Zagadnienia geobotaniczne Pomorza. Poznań: Poznańskie Towarzystwo Przyjacioł Nauk; 1950. [Badania fizjograficzne nad Polską zachodnią; vol 2(4)].

43. Celiński F, Filipek M. Flora i zespoły roślinne leśno-stepowego rezerwatu w Bielinku nad Odrą. Poznań: Poznańskie Towarzystwo Przyjacioł Nauk; 1958. (Badania fizjograficzne nad Polską zachodnią; vol 4).

44. Matuszkiewicz JM, Kozłowska AB. Przegląd fitosocjologiczny zbiorowisk leśnych Polski - ciepłolubne dąbrowy. Fragm Flor Geobot. 1991;36(1):203-256.

45. Pawłowska S. Charakterystyka statystyczna i elementy flory polskiej. In: Szafer W, Zarzycki K, editors. Szata roślinna Polski. Warsaw: Polish Scientific Publishers PWN; 1972. p. 129-206. (vol 1).

46. Babczyńska-Sendek B. Problemy fitogeograficzne i syntaksonomiczne kserotermów Wyżyny Śląskiej. Katowice: Wydawnictwo Uniwersytetu Śląskiego; 2005.

47. Paul W. Xerothermic species of the genus Campanula in Poland - a model for the phylogeographical assessment of reconstruction of post-glacial migration routes. Ann UMCS Biol. 2012;67(1):27-36. http://dx.doi.org/10.2478/v10067-012-0010-3

48. Cyunel E. Studia nad rozmieszczeniem gatunków kserotermicznych w polskich Karpatach Zachodnich. Fragm Flor Geobot. 1959;5(3):409-441.

49. Pawłowski B. Szata roślinna gór polskich. In: Szafer W, Zarzycki K, editors. Szata roślinna Polski. Warsaw: Polish Scientific Publishers PWN; 1972. p. 189-252. (vol 2).

50. Richardson DM, Whittaker RJ. Conservation biogeography foundations, concepts and challenges: conservation biogeography: 
foundations, concepts and challenges. Divers Distrib. 2010;16(3):313320. http://dx.doi.org/10.1111/j.1472-4642.2010.00660.x

51. Dunstan PK, Bax NJ, Foster SD, Williams A, Althaus F. Identifying hotspots for biodiversity management using rank abundance distributions: identifying hotspots using rank abundance distributions. Divers Distrib. 2012;18(1):22-32. http://dx.doi. org/10.1111/j.1472-4642.2011.00838.x

52. Keppel G, van Niel KP, Wardell-Johnson GW, Yates CJ, Byrne M, Mucina L, et al. Refugia: identifying and understanding safe havens for biodiversity under climate change. Glob Ecol Biogeogr. 2012;21(4):393404. http://dx.doi.org/10.1111/j.1466-8238.2011.00686.x

53. Dimitrakopoulos P, Memtsas D, Troumbis AY. Questioning the effectiveness of the Natura 2000 special areas of conservation strategy: the case of Crete. Glob Ecol Biogeogr. 2004;13(3):199-207. http:// dx.doi.org/10.1111/j.1466-822X.2004.00086.x
54. Franklin J. Mapping species distributions: spatial inference and prediction. Cambridge: Cambridge University Press; 2009. (Ecology, biodiversity and conservation).

55. Franklin J. Moving beyond static species distribution models in support of conservation biogeography: moving beyond static species distribution models. Divers Distrib. 2010;16(3):321-330. http://dx.doi. org/10.1111/j.1472-4642.2010.00641.x

56. Kiedrzyński M, Zielińska KM, Kiedrzyńska E, Jakubowska-Gabara J. Regional climate and geology affecting habitat availability for a relict plant in a plain landscape: the case of Festuca amethystina L. in Poland. Plant Ecol Divers. 2014. http://dx.doi.org/10.1080/17550874. 2014.904951

57. Stewart JR, Lister AM, Barnes I, Dalen L. Refugia revisited: individualistic responses of species in space and time. Proc Biol Sci B. 2010;277(1682):661-671. http://dx.doi.org/10.1098/rspb.2009.1272 